\title{
Electric cars: technical characteristics and environmental impacts
}

\author{
Eckard Helmers ${ }^{*}$ and Patrick Marx
}

\begin{abstract}
Background: Electric vehicles have been identified as being a key technology in reducing future emissions and energy consumption in the mobility sector. The focus of this article is to review and assess the energy efficiency and the environmental impact of battery electric cars (BEV), which is the only technical alternative on the market available today to vehicles with internal combustion engine (ICEV). Electricity onboard a car can be provided either by a battery or a fuel cell (FCV). The technical structure of BEV is described, clarifying that it is relatively simple compared to ICEV. Following that, ICEV can be 'e-converted' by experienced personnel. Such an e-conversion project generated reality-close data reported here.

Results: Practicability of today's BEV is discussed, revealing that particularly small-size BEVs are useful. This article reports on an e-conversion of a used Smart. Measurements on this car, prior and after conversion, confirmed a fourfold energy efficiency advantage of BEV over ICEV, as supposed in literature. Preliminary energy efficiency data of FCV are reviewed being only slightly lower compared to BEV. However, well-to-wheel efficiency suffers from 47\% to $63 \%$ energy loss during hydrogen production. With respect to energy efficiency, BEVs are found to represent the only alternative to ICEV. This, however, is only true if the electricity is provided by very efficient power plants or better by renewable energy production. Literature data on energy consumption and greenhouse gas (GHG) emission by ICEV compared to BEV suffer from a 25\% underestimation of ICEV-standardized driving cycle numbers in relation to street conditions so far. Literature data available for BEV, on the other hand, were mostly modeled and based on relatively heavy BEV as well as driving conditions, which do not represent the most useful field of BEV operation. Literature data have been compared with measurements based on the converted Smart, revealing a distinct GHG emissions advantage due to the German electricity net conditions, which can be considerably extended by charging electricity from renewable sources. Life cycle carbon footprint of BEV is reviewed based on literature data with emphasis on lithium-ion batteries. Battery life cycle assessment (LCA) data available in literature, so far, vary significantly by a factor of up to 5.6 depending on LCA methodology approach, but also with respect to the battery chemistry. Carbon footprint over 100,000 km calculated for the converted 10-year-old Smart exhibits a possible reduction of over $80 \%$ in comparison to the Smart with internal combustion engine.

Conclusion: Findings of the article confirm that the electric car can serve as a suitable instrument towards a much more sustainable future in mobility. This is particularly true for small-size BEV, which is underrepresented in LCA literature data so far. While $\mathrm{CO}_{2}$-LCA of BEV seems to be relatively well known apart from the battery, life cycle impact of BEV in categories other than the global warming potential reveals a complex and still incomplete picture. Since technology of the electric car is of limited complexity with the exception of the battery, used cars can also be converted from combustion to electric. This way, it seems possible to reduce $\mathrm{CO}_{2}$-equivalent emissions by $80 \%$ (factor 5 efficiency improvement).
\end{abstract}

\footnotetext{
*Correspondence: e.helmers@umwelt-campus.de

Institut für angewandtes Stoffstrommanagement (IfaS) am Umwelt-Campus

Birkenfeld, Trier University of Applied Sciences, P.O. Box 1380 Birkenfeld,

D-55761, Germany
}

\section{Springer}

(c) 2012 Helmers and Marx; licensee Springer. This is an Open Access article distributed under the terms of the Creative Commons Attribution License (http://creativecommons.org/licenses/by/2.0), which permits unrestricted use, distribution, and reproduction in any medium, provided the original work is properly cited. 


\section{Review}

\section{Introduction}

On a worldwide scale, $26 \%$ of primary energy is consumed for transport purposes, and $23 \%$ of greenhouse gas emissions is energy-related. Street traffic represents a share of $74 \%$ in the transport sector worldwide (IPCC data from 2007, as summarized in [1]). The transport sector includes aircraft, ships, trains, and all types of street vehicles (e.g., trucks, buses, cars and two-wheelers). Automobiles play a particular role for three reasons: First, cars are dominating the street traffic in most countries. Second, car sales exhibit the greatest growth rates in the world. Third, there are alternative technologies for the drivetrain available unlike, e. g., for trucks. While small trucks may also be operated electrically within a limited range, big trucks are dependent on diesel fuel, which can be shifted to a mixture of $80 \%$ methane (either fossil or biogenic) in the future. Buses can also be driven electrically on limited distances; buses driven by compressed natural gas (methane) are routinely used. While fuel cell-driven buses are already on the streets, small trucks driven by fuel cells and $\mathrm{H}_{2}$ are still concepts.

In Germany, for example, cars are responsible for $60 \%$ of all traffic-related $\mathrm{CO}_{2}$ emissions (German Federal Environment ministry number for 2010, summarized in [1]). In the future, traffic is expected to grow enormously worldwide, particularly in developing Asian countries. The worldwide vehicle stock of 630 million may grow to one billion in 2030 (data from Shell 2007, reviewed by Angerer et al. [2]). Vehicle production is expected to grow from 63 to 100 million cars per year until 2030 [2]. In addition to the $\mathrm{CO}_{2}$ emissions, modern internal combustion engine vehicles (ICEVs) still have dangerous toxic emissions. According to the World Health Organization (WHO) [3], air pollution is a major environmental risk for health and is estimated to cause approximately two million premature deaths worldwide per year. Since ozone, fine dust, $\mathrm{NO}_{2}$, and $\mathrm{SO}_{2}$ have been identified by $\mathrm{WHO}$ as being the most dangerous kinds which are mainly, or to a substantial extent, traffic-derived, traffic will be responsible for approximately half of that quantified costs in lives and health. Toxic ICEV emissions cause high health costs even in industrialized countries: Almost 25\% of the European Union (EU)-25 population live less than $500 \mathrm{~m}$ from a road carrying more than three million vehicles per year. Consequently, almost four million years of life are lost each year due to high pollution levels (press release European Environmental Agency, 26 February 2007).

In order to meet future mobility needs, reduce climate as well as health relevant emissions, and phase out dependence on oil ('peak oil'), today's propulsion technologies have to be replaced by more efficient and environmentally friendly alternatives. On the transition to a sustainable society, particularly efficient mobility technologies are needed worldwide. Electric vehicles have been identified as being such a technology [4]. In parallel, a couple of countries (like Germany, Denmark, and Sweden) have decided to switch electricity production from fossil fuel to renewable sources, further improving sustainability of electric cars when compared with ICEV.

\section{Technology \\ Concepts of electric cars}

History At the beginning of the automobile's history, two main competing approaches to engine-driven vehicles existed: one with internal combustion engine (ICE) and another one with an electric drivetrain. Already in 1834, the American inventor Thomas Davenport built the first electric car. The first ICEV was developed in 1886 by Benz and Daimler in Germany. Around the year 1900, electric cars had a significant share of all enginedriven cars. At the same time, F. Porsche already invented a hybrid electric car equipped with an ICE range extender and wheel hub electric engines. The two different drive trains were competing until Henry Ford, in 1908, chose an ICEV for the first mass production of a car in history (summarized in [5]). This way, ICEV won the race early in the twentieth century and displaced the battery electric vehicles (BEV). From an environmental perspective, this may have been one of the biggest mistakes in the history of technology.

Concluding, the BEV does not represent recent 'high tech', but a comparatively simple technical concept, meanwhile available as a series product for more than 110 years. Accordingly, e-conversion, which is the conversion of new or used ICEV to electric cars, can easily be implemented by experienced personnel. In contrast, the modern lithium-ion battery technology, prerequisite for the everyday life practicability of most BEV, is related to very recent technical improvements.

Electric car segments Within the 1990s, electric cars were again offered as series products in California due to its Zero Emission Act (summarized in [5]). After the Zero Emission Act had been suspended, Partial Zero Emission cars were preferred by the Californian government, which prompted the carmaker Toyota to develop the hybrid vehicle, combining electric and combustion engine. Energy efficiency improved drastically this way (see below); also, the idea of the electric car spread 
worldwide parallel to the success of the Toyota Prius. Since a full hybrid vehicle is able to drive electrically, it simply needs a plug and a bigger battery in order to be charged like a BEV. This way, the category of plug-in hybrid vehicles (PHEV) was created. Within the last 10 years, different drivetrain concepts based on electric motors have been developed and are soon going to enter mass production. All-electric drive and hybrid electric drive have to be differentiated. In contrast to the hybrid electric drive, in the all-electric car, an electric motor is the only energy converter. According to a UN definition from 2003, a hybrid electric drivetrain consists of at least two different energy converters (e.g., ICE and electric motor) contributing to the drive system and uses two different energy storages (e.g., fuel and battery) (see, e.g., UNEP [6]).

Additionally, electricity onboard an electric car can be generated by a fuel cell. This technology has been investigated for decades, and production of small series of fuel cell vehicles (FCV) already started or is promised by carmakers to be released within the very next years. An FCV is an electric vehicle with a different energy storage compared to battery electric vehicles. It is equipped with a buffer battery, which is, however, much smaller compared to a BEV [7].

With respect to strategic and market perspectives as well as life cycle impacts of electric cars, their practicability in different segments of car sizes needs to be investigated (Table 1). Car size is most important in BEV since battery size must grow in parallel to the vehicle's weight.

In the next years, electric cars will be mostly small- or mid-size cars due to two main reasons: First, the weight limits the range of operation, which is a factor of suitability for daily use. Second, battery costs establish another main regulating factor: larger cars need bigger and much more expensive batteries.

On the contrary, PHEV and FCV are increasingly useful in the segment of medium-size and large cars because only a small fraction of energy is needed to be carried in the battery. The energy density of compressed hydrogen is close to fossil fuels, very much in contrast to the energy density of available batteries.

\section{Technical components of an electric car}

According to Larminie and Lowry [9], the main components of a BEV can be divided into the electric battery, the electric motor, and a motor controller (Figure 1). The technical structure of a BEV is simpler compared to ICEV since no starting, exhaust or lubrication system, mostly no gearbox, and sometimes, not even a cooling system are needed.

The battery charges with electricity either when plugged in the electricity grid via a charging device or during braking through recuperation. The charger is a crucial component since its efficiency can vary today between $60 \%$ and $97 \%$, wasting $3 \%$ to $40 \%$ of the grid energy as heat. The motor controller supplies the electric motor with variable power depending on the load situation. The electric motor converts the electric energy into mechanical energy and, when used within a drivetrain, to torque. In series BEV produced so far, central engines have been used; however, hub wheel electric engines are also possible and would be available for mass production (summarized in [5]).

Modern, highly efficient electric motors are based on permanent magnetic materials from which the strongest are alloys containing the rare earth elements (REE) neodymium and samarium, respectively. Usual alloys are both NdFeB and SmCo magnets [10].

This has caused some concern since REEs are scarce, and their export is controlled by a few countries, mainly by China (Helmers, unpublished work). However, electric motors for BEV do not necessarily contain REE. There are several types of electric motors, usually divided into alternating current $(\mathrm{AC})$ and direct current (DC) types. There are both AC and DC electric engines built with and without permanent magnets, according to individual use.

In electric cars, traction motors without magnets are quite usual since they are cheaper (Loehr C, personal communication). A subspecies of AC motors are induction motors using no REE. The Tesla Roadster is equipped with an induction motor without REE, as will be the forthcoming Tesla Model $\mathrm{S}$ and the Toyota RAV4EV. In a more detailed view, it can be stated that there are several electric engines available operating

Table 1 Possible market segments of BEV, PHEV, and FCV (after Nemry and Brons [8], completed)

\begin{tabular}{|c|c|c|}
\hline Size of car & BEV & PHEV \\
\hline Small & $\begin{array}{c}\text { Immediate candidate } \\
\text { Most useful according to practicability reasons related } \\
\text { to battery size and costs }\end{array}$ & $\begin{array}{c}\text { Vehicle packaging problem and high price } \\
\text { are obstacles. }\end{array}$ \\
\hline Medium & $\begin{array}{l}\text { Useful } \\
\text { Some models expected within forthcoming years }\end{array}$ & $\begin{array}{l}\text { Privileged segment. Long distance } \\
\text { trips possible. However, } \mathrm{H}_{2} \text { filling station } \\
\text { infrastructure required for FCV. }\end{array}$ \\
\hline Large & $\begin{array}{c}\text { Conceivable for specific markets only (e.g., luxury cars) } \\
\text { due to high price and limited range }\end{array}$ & \\
\hline
\end{tabular}




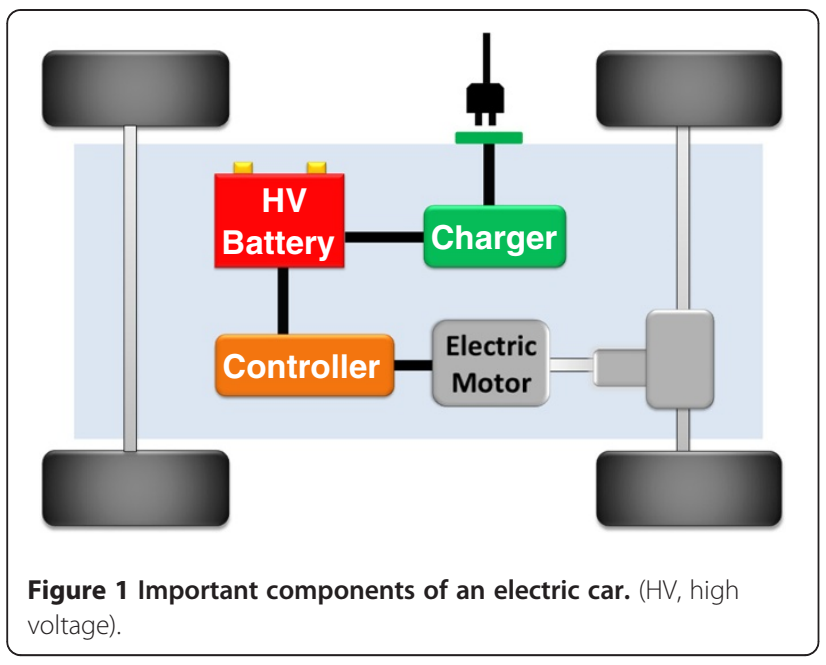

without REE magnets: conventional mechanically commutated DC machines, the asynchronous machines, the load-controlled synchronous machines with electrical excitation, and the switched reluctance motors (Gerke W, personal communication). This gives the motor industry some flexibility.

\section{Batteries for electric cars}

It is still possible and useful to equip electric vehicles with lead-acid batteries. Cars of the Californian interim electric vehicle boom in the 1990s were partly driven by lead batteries (Table 2), nevertheless already offering a driving performance comparable to ICE cars. Today, for example, there are small electric trucks commercially available and equipped with lead batteries and a capacity of 13 to 26 $\mathrm{kWh}$, allowing a maximum range of up to $200 \mathrm{~km}$ and a maximum speed of $60 \mathrm{~km} / \mathrm{h}$ (numbers taken from a prospectus of Alkè Company, Italy, 2010). Also, a certain share of today's electric cars (e.g., by the Indian company REVA) are equipped with $\mathrm{Pb}$ batteries. In order to diversify the future battery technology and materials, it would be useful to keep $\mathrm{Pb}$ traction batteries for certain applications. Electric cars for smaller ranges, as e.g., in-town driving, socalled neighborhood electric vehicles, will be much cheaper if they are operated with lead-acid batteries instead of a lithium-ion battery. Additionally, there are recent performance improvements of the lead battery, thanks to a gel matrix and gassing charge [11].

However, the enormous increase in energy density offered by Li-ion batteries is the prerequisite for the expected widespread electrification of cars. Nickel metal hydride batteries were used in the interim time when the re-electrification of the automobile started in the 1990s. However, they do not offer enough power and have a worse environmental impact compared to Li-ion batteries (see below). The only alternative to Li-ion batteries with comparable power, the Zebra cell (Table 2), is based on molten salt and, thus, only useful for continuous every day use. Today, a lot of different Li chemistries are available, and prices are continuously decreasing for $\mathrm{Li}$ ion batteries (e.g., summarized in [12]). However, the price for a complete Li-ion cell set offering $14 \mathrm{kWh}$ capacity, allowing a $100-\mathrm{km}$ electrical range of a small-size car (like a Smart, see below), is still in the order of 5,000 Euro including taxes. Life cycle impacts of the various Li-ion chemistries differ significantly (see below).

\section{Environmental impact of electric cars Well-to-wheel efficiency of electric cars}

Considering the enormous worldwide increase of mobility expected for the future, the reduction of automobile energy

Table 2 Important materials commercially used in traction batteries for electric vehicles since 1998

\begin{tabular}{|c|c|c|c|c|}
\hline Battery type & Active chemical components & Energy density $(\mathrm{Wh} / \mathbf{k g})$ & Costs (Euro/kWh) & Cars (examples) \\
\hline \multirow[t]{2}{*}{ Lead-acid } & $\mathrm{Pb} / \mathrm{PbO}_{2}$ & 30 to $35^{a}$ & up to $100^{\mathrm{d}}$ & \multirow[t]{2}{*}{ GM EV1 (1996 to 1999), REVA } \\
\hline & $\mathrm{H}_{2} \mathrm{SO}_{4}$ & 10 to $40^{\mathrm{b}}$ & 100 to $150^{\text {a }}$ & \\
\hline \multirow{3}{*}{$\begin{array}{l}\text { Nickel metal } \\
\text { hydrides (NiMH) }\end{array}$} & \multirow{3}{*}{$\begin{array}{l}\text { various alloys, as e.g., } \\
\text { LaNdNiCoSi }\end{array}$} & 60 to $70^{\mathrm{a}}$ & 300 to $350^{\mathrm{a}}$ & \multirow[t]{3}{*}{ Toyota RAV4EV-I (1997-2003), Toyota Prius I-II } \\
\hline & & $80^{c}$ & & \\
\hline & & 50 to $105^{b}$ & & \\
\hline \multirow[t]{2}{*}{ Zebra } & \multirow[t]{2}{*}{$\mathrm{NaCl}-\mathrm{Ni}$} & $150^{c}$ & $500^{e}$ & \multirow[t]{2}{*}{ Th!nk City, Smart EV, Smith Electric Vehicles } \\
\hline & & 80 to $120^{b}$ & & \\
\hline \multirow[t]{6}{*}{ Lithium-ion } & Li-Ni-Co-Al & all types of chemistry: & 500 to $750^{f}$ & \multirow{6}{*}{$\begin{array}{c}\text { Thlink City, Mitsubishi I-MiEV, GM Volt/Opel } \\
\text { Ampera, Nissan Leaf, Tesla }\end{array}$} \\
\hline & Li-Ni-Mn-Co & 120 to $150^{\mathrm{a}}$ & 500 to $1,000^{9}$ & \\
\hline & $\mathrm{LiMn}_{2} \mathrm{O}_{4}$ & & & \\
\hline & Li-titanate & 85 to $160^{b}$ & & \\
\hline & $\mathrm{LiFePO}_{4}$ & & $370^{\text {h }}$ (cells only) & \\
\hline & Li-Polymer (LiPo) & & & \\
\hline
\end{tabular}

Data sources: a http://nachhaltigkeit.daimler.com/reports/daimler/annual/2010/nb/German/30201060/elektrische-antriebe.html 3/2011. ' $[12] .{ }^{c}$ www.chemie.de (2011). ${ }^{d}[11] .{ }^{e}[13] . ~{ }^{f}$ Own market survey, spring 2011. ${ }^{g}$ Reviewed in [14]. ${ }^{h}$ Price for the cells from Chinese production offered in Germany including taxes (November 2011). 
demand is one of the most important challenges. In order to evaluate the technologies available, energy consumption is divided into the well-to-tank (WTT) and the tank-towheel (TTW) demands. WTT refers to the stage from the extraction of feedstock until the delivery of fuel to the vehicle tank [15]. TTW quantifies the performance of the drivetrain. Together, both result in the overall well-to-wheel (WTW) efficiency. The WTW evaluation allows estimation of the overall energy and efficiency of automobiles powered by different propulsion technologies (Table 3 ).

Considering the fact that cars (light duty vehicles) are so important for worldwide public and private transport, it is astonishing that there are only two technical alternatives to the established ICEV available in the market: battery electric cars and hydrogen-powered fuel cell cars (Table 3). Cars equipped with hydrogen-powered fuel cells, however, are not yet available as series products, but manufacturers like MercedesBenz and Toyota promised to be close to releasing or have already released a small series of FCV. The main advantage of a FCV compared to a BEV is a much bigger range and quick refilling of the tank. However, the necessary $\mathrm{H}_{2}$ filling station infrastructure is available nowhere in the world, not regarding some single filling stations in a few city centers allowing regional mobility of hydrogen-powered fuel cell vehicles, which must return daily to the same filling station.
Efficiency units Efficiencies of different propulsion technologies may be expressed either by $\mathrm{CO}_{2}$ equivalent emissions per course unit (e.g., $\mathrm{CO}_{2} / \mathrm{km}$ ), by energy units $(\mathrm{MJ} / \mathrm{km})$, or by percentages looking at the energy transformed to motion. Since petrol (in US: gas), diesel, LPG (propane + butane) as well as natural gas (methane) are all hydrocarbons and burn to mainly $\mathrm{CO}_{2}$ while releasing energy, the consumed energy and the $\mathrm{CO}_{2}$ emissions are proportional. If WTW data are expressed in energy units or $\mathrm{CO}_{2}$ emissions, they may allow assessing different technology alternatives at least within the ICE sector. Often, these data include both the fuel chain and the operation of cars (e.g., [22]). However, comparing WTW data of ICEV with alternative technologies is usually complicated by the lack of data and testing schemes for alternative technologies. Good (realistic) data of one technology compared with bad (unrealistic) data regarding the alternative technology can fundamentally change the results of the efficiency evaluation or, following that, the life cycle assessment (LCA) comparison. We decided to review efficiency percentages (Table 3) of the available propulsion technologies for greater transparency. This way, the wrong impression of higher accuracy than available from the data, as well as erroneous conclusions, is avoided while comparing data of ICEV with alternative technologies.

Table 3 Energy efficiency of the propulsion technologies available to the market (in percentages)

\begin{tabular}{|c|c|c|c|c|}
\hline Propulsion technology & WTT (\%) & TTW (\%) & WTW (\%) & WTW calculated (\%) \\
\hline \multicolumn{5}{|l|}{ ICE } \\
\hline Petrol (gasoline) & $79^{a}, 86^{b}$ & $16^{\mathrm{a}}, 23^{\mathrm{k}}$ & $10^{\circ}, 13^{\mathrm{a}}, 12$ to $14^{\mathrm{p}}, 14^{\mathrm{q}}, 20^{\mathrm{r}}$ & 13 to 20 \\
\hline Petrol (gasoline) full electric hybrid & $79^{\mathrm{a}}, 86^{\mathrm{b}}$ & $30^{\mathrm{k}}, 37^{\mathrm{a}}$ & $15^{\circ}, 17$ to $22^{\mathrm{p}}, 29^{\mathrm{a}, \mathrm{q}}$ & 24 to 32 \\
\hline Diesel & $76^{c}, 82^{a}, 84^{b}$ & $23^{\mathrm{a}}, 28^{\mathrm{k}}$ & $13^{\mathrm{o}}, 16$ to $18^{\mathrm{p}}, 19^{\mathrm{a}}, 25^{\mathrm{r}}$ & 18 to 24 \\
\hline \multirow[t]{2}{*}{ LPG (propane + butane) } & $88^{d}, 93^{e}$ & $16^{\mathrm{e}}$ & $11^{\circ}, 15^{\mathrm{e}}$ & 14 to 20 \\
\hline & & petrol ref. $+6^{1}$ & & \\
\hline \multirow[t]{2}{*}{ CNG (methane) } & 65 to $86^{f}, 85^{e}$ & $16^{e}$ & $12^{\circ}, 14^{\mathrm{e}}, 21^{\mathrm{r}}$ & 10 to 22 \\
\hline & & petrol ref. $+9^{m}$ & & \\
\hline \multicolumn{5}{|l|}{ FCV } \\
\hline $\mathrm{H}_{2}$ fuel cell (gaseous $\mathrm{H}_{2}$ stored in pressure tanks) & $37^{9}, 40^{c}, 53^{h}$ & $50^{\mathrm{a}}, 56^{\mathrm{k}}$ & 20 to $23^{p}, 22^{a}, 23^{s}, 29^{q}$ & 19 to 30 \\
\hline \multicolumn{5}{|l|}{ BEV } \\
\hline Electric car (literature) & & $73^{k}, 80$ to $90^{n}$ & 59 to $80^{t}, 74^{k}$ & \\
\hline Electric car minimum ${ }^{\mathrm{i}}$ & $15^{\mathrm{i}}$ & $73^{k}$ & & 11 \\
\hline Electric car optimum ${ }^{i}$ & 59 to $85^{j}$ & $90^{n}$ & & 53 to 77 \\
\hline
\end{tabular}

WTW in the last column calculated from WTT and TTW literature as indicated. WWT, well-to-tank; TTW, tank-to-wheel; WTW, well-to-wheel; LPG, liquefied petroleum gas; CNG, compressed natural gas; ICE, internal combustion engine; FCV, fuel cell vehicle; BEV, battery electric vehicle. ${ }^{\mathrm{a}}[7]$. ${ }^{\mathrm{b}} \mathrm{Kavalov}$ and Peteves [15].

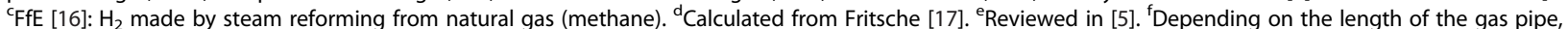
between $14 \%$ and $35 \%$ of the energy content can be used up in the chain (calculated for natural gas in the European market in [18]). ${ }^{9}[19]: \mathrm{H}_{2}$ made by

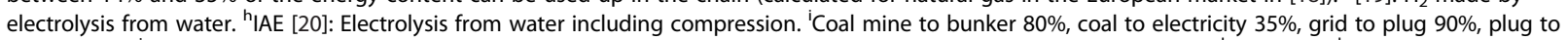
battery $60 \%$. 'Wind energy transmission $97 \%$, [storage power station (water) $70 \%$ ], grid to plug $90 \%$, plug to battery $97 \%$. ${ }^{\text {K}}$ Kloes [21]. ${ }^{1}$ A compression optimized engine can increase efficiency by up to $6 \%$ (Heinze T, Saarbrücken THW, personal communication 2011). ${ }^{\mathrm{I}}$ In a single fuel engine, compression ratio can be optimized to achieve an energy efficiency increase of $9 \%$ over the patrol reference EU [22]. ${ }^{n}$ Husain [23]. ${ }^{\circ}$ [24] (Light duty vehicles with curb weight 1.6 to $1.8 \mathrm{t}$ evaluated). ${ }^{\mathrm{P}}$ Reviewed by An and Santini [25]. ${ }^{\mathrm{a}} \mathrm{Pelz} \mathrm{N}$ [26]. '[27]. ${ }^{\mathrm{S}}$ Bossel [28]. ${ }^{\mathrm{t}}$ Reviewed by Hacker et al. [29]. 
Inhomogeneous database The available database is enormous but should be regarded inhomogeneous and, for some parts, as questionable. Some studies are based on modeled data (virtual cars), some on laboratory measurements with isolated engines, and some based on unified test schemes about actually driving the car. Some measurements were performed on laboratory test stands, others on real streets. They are also based on cars with various curb weights. Accordingly, there are strongly deviating results: Sullivan et al. [30], for example, resumed that, by 2015, diesel-driven cars will (still) have $14 \%$ to $27 \%$ less $\mathrm{CO}_{2}$ emission due to a higher TTW efficiency, compared to petrol-fuelled cars and based on German certification data. But in reality, consumers preferred bigger motorization than modeled. A comparison by a German non-governmental organization revealed that certified $\mathrm{CO}_{2}$ emissions of new diesel cars on German streets increased since 2000 and coincided with falling $\mathrm{CO}_{2}$ emissions of new petrol-fuelled cars at $173 \mathrm{~g} \mathrm{CO}_{2} / \mathrm{km}$ in 2006 (reviewed by Helmers [1]).

Standardized driving cycles: Contrast to reality A major problem in well-to-wheel efficiency studies is that most data are based on artificial test procedures, which are also different from one region of the world to another. The German Ministry of Transport, Building and Urban Development recently demonstrated [31] that the majority of cars consume around 25\% more fuel and thus emit more $\mathrm{CO}_{2}$ than certified. Most of more than 100 cars investigated are within $40 \%$ of excess, while a few percent of the vehicles in this spot check revealed fuel consumption up to $70 \%$ higher than certified due to the European test scheme [31]. A worldwide unified test scheme is therefore currently under international negotiation [31]. If this unified driving cycle includes alternative propulsion technologies, it could serve as a basis to generate more reliable TTW data in the future.

Internal combustion engine vehicles ICEVs are powered by petrol (gasoline), diesel, propane and butane, or methane (Table 3). These fossil hydrocarbons may be substituted or exchanged with biofuels like bioethanol, biodiesel, or biomethane, which is not the subject of this paper. An integrated greenhouse gas (GHG) assessment of the process chains of natural gas and industrialized biomethane is provided by Arnold et al. [32], revealing that GHG emission data will change in the future due to the development of new sources and markets like, e.g., the growing market for liquefied natural gas. WTT data for petrol (gasoline), diesel, propane and butane, and methane provisions reveal that up to $24 \%$ of the contained energy is already being consumed within the chain. In the exceptional case of methane, pumped trough up to 7,000 km from Siberia to Europe, there is a WTT loss of up to $35 \%$ (Table 3 ).
In general, tank-to-wheel efficiencies of ICEV are very low with $10 \%$ to $25 \%$ because $75 \%$ to $90 \%$ of the energy is lost as heat instead of propelling the car. However, ICEV has been successful on the market for more than a century due to the very high energy density (up to 20 times higher compared to Li-ion batteries) of carbonbased fuels available worldwide since over 100 years for low prices. The electric hybrid ICE concept brought an efficiency jump; TTW's of hybrid ICE roughly doubled compared to that of ICEV without electric assistance (Table 3). Toyota, in 1997, introduced this technology to the market in a large-scale production, followed by Honda in 1999 (reviewed in [5]).

ICEV powered by gaseous hydrocarbons, namely methane, and propane and butane, are similarly inefficient like petrol-powered cars. However, if the higher caloric value is used for achieving higher compression, gas-driven propulsions can be as efficient as the diesel engine ( $+6 \%$ to 9\% TTW, see Table 3). Unfortunately, car manufacturers do not utilize the potentials of gaseous propulsions so far. Altogether, WTW calculations reveal that, during the operation of ICEV, between $68 \%$ and $90 \%$ of the entire energy is wasted (Table 3).

FCV as alternative propulsions Within the two technical alternatives available, $\mathrm{H}_{2}$-powered fuel cell vehicles reveal a problem, which is losing $50 \%$ to $60 \%$ energy each during fuel production (here both from hydrogen production by steam reforming as well as by water electrolysis) and during fuel cell operation and driving. Altogether, WTW efficiency of FCV seems to be nearly as low as the efficiency of ICEV, with $19 \%$ to $30 \%$ (=70\% to $81 \%$ energy loss). However, in terms of $\mathrm{CO}_{2}$ emissions, several authors see WTW advantages of FCV over ICEV (e.g., [22]); see below.

BEV analysis in terms of WTT, TTW, and WTW efficiency generates a complex picture First, electricity production can take place under very different conditions: When electricity is generated from fossil sources in an inefficient power plant and loaded with an inefficient charger to the $\mathrm{BEV}$, up to $85 \%$ of the energy may be lost, resulting in a WTW efficiency of only $11 \%$ comparable to petrol-operated ICEV (Table 3). Actually, in a pre-series BEV, car chargers with only $60 \%$ efficiency have been implemented. Today's most efficient battery chargers, however, have efficiencies of up to $97 \%$. Today, chargers are mostly implemented in the car, while in the California BEV of the 1990s, they were partly not integrated in the cars, complicating the comparability of older WTW numbers.

Today, WTWs reported for BEV are between 59\% and $80 \%$. This high efficiency is due to the fact that only very little energy is wasted in the drivetrain (Table 3). 
Altogether, BEV represent the only alternative technology offering an efficiency jump in individual mobility, consuming up to four times less energy than today's cars. This has been confirmed during measurements on a car converted from combustion engine to electric (see below).

However, BEV should be primarily and increasingly loaded with electricity from renewable sources and must be equipped with an efficient charging unit (Table 3). Although being much more efficient so far, BEV cannot cover all mobility needs due to range restrictions, so the other technologies (ICE and FCV) are still needed under sustainability-optimized conditions.

From efficiency to energy units Consumption of the competing technologies in terms of energy units should also be known. Ideally, data should be taken from the same car as an ICE as well as an electrical version, which is unfortunately not available on the market. Therefore, in 2011, a Smart car has been converted from petrol to electric in the laboratory of the authors, revealing realistic data (technical specifications see below). This car consumed 5.3 $\mathrm{L}$ petrol $/ 100 \mathrm{~km}$, as quantified during a test cycle under standard road conditions with an original 40-kW engine prior to the replacement of the propulsion, which can be converted to $1.67 \mathrm{MJ} / \mathrm{km}$. The test cycle was based on a $46.8-\mathrm{km}$ route consisting of villages $(20 \%, 50 \mathrm{~km} / \mathrm{h})$, autobahn $(24 \%, 100 \mathrm{~km} / \mathrm{h})$, and country roads $(80 \mathrm{~km} / \mathrm{h})$. The same test cycle was driven before and after electric conversion, both at air temperatures of $15^{\circ} \mathrm{C}$ to $20^{\circ} \mathrm{C}$, without heating (no A/C available); the car has been weighed each time. After installing a $25-\mathrm{kW}$ electric engine, the electrified Smart had better acceleration and consumed 14.5 $\mathrm{kWh} / 100 \mathrm{~km}$ on the above test cycle, including charge losses, which are equivalent to $0.5 \mathrm{MJ} / \mathrm{km}$. This number is reflected in literature: Majeau-Bettez et al. [33] based his LCA calculations on a BEV electricity consumption of 0.5 $\mathrm{MJ} / \mathrm{km}$. Since the weight of the Smart increased by $22.2 \%$ due to the added Li battery (additional information given below), the weight-normalized energy consumption of the electrified Smart is $0.4 \mathrm{MJ} / \mathrm{km}$. This realistic experiment fairly reveals the fourfold energy efficiency advantage of electric cars proposed in literature and reviewed in Table 3: ICEV operated with petrol has only $16.5 \%$ (13\% to $20 \%$ ) TTW energy efficiency, while electric cars today are believed to achieve $65 \%$ (53\% to $77 \%$ ) WTW, which is a four-times higher energy efficiency (Table 3).

It is of course more difficult to get street data for FCV. The first realistic hydrogen consumption data of pre-series cars are reported by car magazines, revealing, e.g., $1.11 \mathrm{~kg}$ of 700 bar $\mathrm{H}_{2} / 100 \mathrm{~km}$ for a Mercedes F-cell B-class car (pre-series model) with a curb weight of $1,809 \mathrm{~kg}$ [34]. The $\mathrm{H}_{2}$-consumption of a Honda FCX Clarity is only slightly higher, considering its lower tank pressure [35].
Due to the German Hydrogen and Fuel-Cell Association [36], hydrogen of 700 bars pressure contains $1.3 \mathrm{kWh} / \mathrm{L}$ of energy (specific gravity $40.2 \mathrm{~kg} / \mathrm{m}^{3}$ ). This way, energy consumption of the B-class fuel cell car can be converted to $35.9 \mathrm{kWh} / 100 \mathrm{~km}$ or $1.3 \mathrm{MJ} / \mathrm{km}$, respectively. Converted to the curb weight of the electrified Smart $(880 \mathrm{~kg})$, only $0.65 \mathrm{MJ} / \mathrm{km}$ would be spent by a FCV of the same weight, which is about one third more than the electric car consumes $(0.5 \mathrm{MJ} / \mathrm{km})$. This also matches the energy consumption of a FCV vehicle modeled by Simons and Bauer [37], revealing $0.68 \mathrm{MJ} / \mathrm{km}$ (converted to a vehicle's weight of $880 \mathrm{~kg}$ ). Linssen et al. [38] simulated between 0.95 and $1.57 \mathrm{MJ} / \mathrm{km}$ for small and large FCV vehicles (860 to 1,270 kg weight), respectively, which are based on compressed hydrogen technology.

A B-class car of today with ICE engine extrapolated to the same weight $(1.8 \mathrm{t})$ would consume $11.6 \mathrm{~L} / 100 \mathrm{~km}$ (certified fuel consumption taken from manufacturers specification $+25 \%$ reality supplement, and extrapolated to $1.8 \mathrm{t}$ ) equivalent to $3.7 \mathrm{MJ} / \mathrm{km}, 2.8$ times the fuel cell version. The TTW-proportion FCV/ICE (petrol) is 2.7, according to the literature (Table 3 ). In conclusion, energy efficiency of a fuel cell car seems to be not far away from the BEV. However, the WTT efficiency of pressurized hydrogen is bad since up to $63 \%$ energy is lost within the delivery chain (Table 3) This led to criticism about driving with hydrogen as fuel (e.g., [28]). However, under unfavorable conditions, efficiency of electricity provision to a BEV can be even worse (Table 3).

\section{Greenhouse gas emissions of electric cars in operation}

Battery electric vehicles (BEV) The greenhouse gas emissions of the BEV can easily be calculated based on its electricity consumption and following the GHG emission associated with the local electricity production $[1,5]$. In the literature, there are plenty of data quantifying greenhouse gas emissions of electric cars in operation (e.g., [39]).

The crucial number in this context is the electricity consumption of electric cars under street conditions. In a review evaluating 21 studies from 1999 to 2009 (18 studies therein from 2007 to 2009), BEV and PHEV consumed a mean of $17.5 \mathrm{kWh} / 100 \mathrm{~km}$ [29]. In contrast, in a few studies focused on LCA quantification, a much higher electricity consumption has been supposed: For example, Helms et al. [40] based their modeling on an electricity consumption of $20.4 \mathrm{kWh} / 100 \mathrm{~km}$ in urban areas, $20.8 \mathrm{kWh} / 100 \mathrm{~km}$ in extra-urban areas, and 24.9 $\mathrm{kWh} / 100 \mathrm{~km}$ on the highway, respectively. Pehnt et al. [41] summarized 21 to $24 \mathrm{kWh} / 100 \mathrm{~km}$. Held and Baumann [42] based LCA quantifications on electricity consumptions of $18.7 \mathrm{kWh} / 100 \mathrm{~km}$ for a mini-class BEV (736 kg curb weight, size of Smart, see below) and 22.9 $\mathrm{kWh} / 100 \mathrm{~km}$ for a compact-class BEV (specified curb 
weight $1,115 \mathrm{~kg})$. In some cases, the assumed electricity consumption of a standard BEV seems to be quite high since only mid-size cars equipped with heavy batteries are taken for calculation (e.g., by Helms et al. [40] based on a BEV with 1,600 kg curb weight).

On the contrary, we assume that, in the next few years, electric cars will be mostly small or mid-size cars (see above). An e-conversion project, performed in the laboratory of the authors in 2011, may illustrate weight data exemplarily: A Smart built in the year 2000 has been e-converted from combustion engine to an electric car. A $25-\mathrm{kW}$ electric engine and a $14-\mathrm{kWh} \mathrm{LiFePO}_{4}$ battery were installed, allowing a range of up to $120 \mathrm{~km}$. The curb weight grew by $161 \mathrm{~kg}$ to $880 \mathrm{~kg}$, which is little more than half of the car weight assumed by Helms et al. [40]. A Mitsubishi I-MiEV weighs $1,110 \mathrm{~kg}$ and is equipped with a 16-kWh Li-ion battery [43]. The Nissan Leaf, however, the first high-volume mid-size electric car, weighs $1,525 \mathrm{~kg}$ and operates a $24-\mathrm{kWh}$ lithium battery [44].

Furthermore, BEV electricity consumption data underlying LCA modeling and indicating, e.g., a yearly $\mathrm{CO}_{2}$ emission of a car fleet are necessarily more or less theoretical today (e.g., [8]). Here again, consumption data derived from certified driving cycles are simulating much lower fossil fuel consumptions for ICEV than realistic and, on the contrary, probably higher than realistic for $\mathrm{BEV}$, as established in the following. We suggest that street condition fuel consumption should be compared for both BEV and ICEV, including charging losses for BEV of course. Only a few real-life electricity consumption data are available so far, which usually cannot be found in scientific literature. The Smart Fortwo converted to an electric car in the laboratory of the authors consumes $14.5 \mathrm{kWh} / 100 \mathrm{~km}$ on the above described test cycle. A Mitsubishi i-MiEV, the first high-volume electric car on the market, consumes $16.94 \mathrm{kWh} / 100 \mathrm{~km}$ on the street [45]. As expected from an electric car, consumption is lowest inside the city, where ICEV conversely exhibit highest fuel consumptions. The Mitsubishi I-MiEV demonstrated the following electricity consumption data during ADAC-testing: $11.3 \mathrm{kWh} /$ $100 \mathrm{~km}$ (urban), $15.0 \mathrm{kWh} / 100 \mathrm{~km}$ (extra-urban), and 24.6 $\mathrm{kWh} / 100 \mathrm{~km}$ on the autobahn at higher speed, respectively [45]. This highlights again the need for a critical data evaluation: BEV will replace ICEV mainly in the local urban area or within local regional traffic, generating possibly higher $\mathrm{CO}_{2}$ advantages than seen in the data derived from standard cycle consumption of BEV and ICEV. Interestingly, Mitsubishi publishes $13.5 \mathrm{kWh} / 100 \mathrm{~km}$ due to the ECE R101 cycle [43], which confirms the independent test results (cited above) for urban and extra-urban consumption.

On the other hand, electricity consumption specified by manufacturers of $\mathrm{BEV}$ can be too low to be realistic.
For example, Tesla motors claims its $1,230-\mathrm{kg}$ roadster consumes only $11 \mathrm{kWh} / 100 \mathrm{~km}$ [46]. Nissan Leaf is the second high-volume BEV available on the market and the first series BEV specially developed for electrical driving. USEPA certifies electricity consumption of the BEV Nissan Leaf (curb weight 1,525 kg [44]) as $19.9 \mathrm{kWh} / 100$ $\mathrm{km}$ in the city and $23.0 \mathrm{kWh} / 100 \mathrm{~km}$ on the highway, respectively [47]. Unlike the European driving cycles, EPA certifications are claimed to be more realistic since they contain 'faster speeds and acceleration, air conditioner use, and colder outside temperatures than usual until 2008' [47]. Nissan itself specifies electricity consumption of its Leaf as $17.3 \mathrm{kWh} / 100 \mathrm{~km}$ [44]. A Mercedes A-class pre-series electric car has been tested, resulting in 19 $\mathrm{kWh} / 100 \mathrm{~km}$ [48]. In conclusion, an electricity consumption of up to $20 \mathrm{kWh} / 100 \mathrm{~km}$ should be realistic for a European mid-size car moved in urban areas or extra-urban at limited speeds, which is the favorite use of electric cars. The $20 \mathrm{kWh} / 100 \mathrm{~km}$ electricity consumption has also been confirmed by a scientific review process (personal communication, [HJ Althaus, 2011]).

Accordingly, we can assume a realistic electricity consumption of 15 to $20 \mathrm{kWh} / 100 \mathrm{~km}$ for urban and extraurban traffic. European small-size cars (like Smart or IMiEV) will be located in the lower end, while European mid-size cars (like Nissan Leaf) will be found in the higher end of this range. Large-size BEV and BEV driven at higher speeds (autobahn) can be expected to consume more than $20 \mathrm{kWh} / 100 \mathrm{~km}$. However, in the forthcoming years, large-size BEV will probably not be the dominant application within the sector of electric cars.

The lower the carbon impact accompanying the electricity production in a country, the lower is the greenhouse gas emissions of the BEV in operation. However, countries such as Australia, China, India, Poland, and South Africa produce between $68 \%$ and $94 \%$ of their electricity by combustion of coal [50]. Coal represents $78 \%$ of China's electricity generation [51], resulting in $743 \mathrm{~g} \mathrm{CO}_{2} / \mathrm{kWh}$ (IEA, number for 2009). According to Yan and Crookes [51], Chinese coal-based electricity production generates $\mathrm{CO}_{2}$ emissions in the range of 194 to $215 \mathrm{~g} / \mathrm{km}$ operating a $\mathrm{BEV}$, which is much higher compared to the 84 to $113 \mathrm{~g} /$ $\mathrm{km}$ of BEV operated in Germany under grid conditions (563 $\mathrm{g} \mathrm{CO}_{2} / \mathrm{kWh}$ [52, number for 2010]) and for BEV consuming 15 to $20 \mathrm{kWh} / 100 \mathrm{~km}$.

However, operating a BEV in China anyhow can lead to significant GHG savings if compared to ICEV operated with Chinese coal-to-liquid (CtL) production fuel. For CtL of this kind, the carbon emissions are 717 to $787 \mathrm{~g} \mathrm{CO}_{2} /$ $\mathrm{km}[51]$.

Plug-in hybrid electric vehicles PHEV has an electricity consumption quite similar to $\mathrm{BEV}$ as long as they drive electric. Weight and cost savings due to a smaller battery 
are compensated by an additional combustion engine (also called range extender). Hacker et al. [29] reviewed eight studies on PHEV revealing a mean electricity consumption of $17.4 \mathrm{kWh} / 100 \mathrm{~km}$. However, depending on the size of the battery and concept of the individual car, the electric range of PHEV is smaller than the range of BEV: The first high-volume PHEV, the GM Volt/Opel Ampera, has a 40to $80-\mathrm{km}$ range according to its carmaker [53], while the Toyota Prius plug-in (2012) will have an electrical range of around $20 \mathrm{~km}$ only. Electricity consumption in electrical mode and fuel consumption during operation of the combustion engine are known only from publications of the motor press and represent preliminary results allowing a rough estimation of their GHG emissions in operation: Auto Motor Sport [54] reported $23.5 \mathrm{kWh} / 100 \mathrm{~km}$ in the electrical mode as well as $6.7 \mathrm{~L}$ petrol $/ 100 \mathrm{~km}$ in the ICE modus for the Opel Ampera. AutoBild [55] reported 22.6 $\mathrm{kWh} / 100 \mathrm{~km}$ in the electrical modus versus $7.7 \mathrm{~L}$ petrol/ $100 \mathrm{~km}$. A GHG impact compilation for a 100-km driving cycle of the Opel Ampera (60 km electrical range plus 40 $\mathrm{km}$ of driving with combustion engine, no charging underway) results in $159 \mathrm{~g} \mathrm{CO}_{2} / \mathrm{km}$ based on the following assumptions: $563 \mathrm{~g} \mathrm{CO} / \mathrm{kWh}$ for German electricity (number for 2010 [52]), 2,310 $\mathrm{g} \mathrm{CO}_{2}$ due to the combustion of $1 \mathrm{~L}$ petrol [5], and supply chain emissions of $506 \mathrm{~g} \mathrm{CO}_{2} /$ L petrol (calculated from Öko-Institut [56]). Carmaker Opel, however, specifies a value of $27 \mathrm{~g} \mathrm{CO}_{2} / \mathrm{km} \mathrm{[53].}$

A Toyota Prius plug-in consumes $3.4 \mathrm{~L}$ petrol/100 km in ICE mode according to an ADAC test [57] and $21.8 \mathrm{kWh} /$ $100 \mathrm{~km}$ in the electrical mode [58], respectively. The journal AutoBild [58] measured $3.8 \mathrm{~L}$ petrol/100 km in ICE mode. Regarding an electrical range of $20 \mathrm{~km}$, this results in an emission of $106 \mathrm{~g} \mathrm{CO}_{2} / \mathrm{km}$ (calculated for $100 \mathrm{~km}$ ). Carmaker Toyota specifies $59 \mathrm{~g} \mathrm{CO}_{2} / \mathrm{km}$ due to ADAC [57].

Over a 100,000-km lifetime (this number chosen in order to ensure comparability with LCA calculations shown below), an Opel Ampera would sum up $15.9 \mathrm{t}$ $\mathrm{CO}_{2}$, while a Toyota Prius plug-in comes to $10.6 \mathrm{t}$ of $\mathrm{CO}_{2}$, respectively, both charged under German mean electricity grid conditions. However, these lifetime balances for PHEV operation are based on the assumption that the battery is completely discharged every time and every trip continues with petrol. In reality, operational lifetime carbon footprints vary strongly with respect to individual use of the cars.

These preliminary findings on the first two reality PHEV exhibit that efficiency and ecoimpact of PHEV will vary very much depending on the technical conception, which is expected to diversify. Moreover, it depends on the average distances traveled in daily use where the two propulsion modes are mixed together.

Fuel cell cars Linssen et al. [38] have quantified the $\mathrm{CO}_{2}$-equivalents of different supply paths of hydrogen based on natural gas as the hydrogen resource and including pressurization and transport. $\mathrm{CO}_{2}$ emission of German $\mathrm{H}_{2}$ production would result in $96 \mathrm{~g} / \mathrm{MJ}$, while a Norwegian production would result in $83 \mathrm{~g} / \mathrm{MJ}$, respectively [38]. FCV energy consumption between 0.65 for small FCV (car weights see above) and $1.57 \mathrm{MJ} / \mathrm{km}$ for large FCV, respectively [38], results in 54 to $151 \mathrm{~g} \mathrm{CO}_{2} / \mathrm{km}$. Eberhard and Tarpenning [46] published a consumption of $152 \mathrm{~g} \mathrm{CO}_{2} /$ $\mathrm{km}$ for the Honda FCX operated in the USA. This order of magnitude was also confirmed by Höhlein and Grube [59], who also concluded that, for $\mathrm{H}_{2}$ generated by electrolysis and powered by wind electricity, $\mathrm{CO}_{2}$ supply path costs can be lower than $25 \mathrm{~g} / \mathrm{km}$. Simons and Bauer [37] calculated $\mathrm{CO}_{2}$-equivalent costs of around $150 \mathrm{~g} \mathrm{CO}_{2} / \mathrm{km}$ (steam methane reforming from natural gas), $105 \mathrm{~g} \mathrm{CO}_{2} /$ $\mathrm{km}$ (biomass in a steam methane reforming process of gasified wood), $320 \mathrm{~g} \mathrm{CO}_{2} / \mathrm{km}\left(\mathrm{H}_{2}\right.$ electrolysis powered with the European grid electricity), or $80 \mathrm{~g} \mathrm{CO}_{2} / \mathrm{km}\left(\mathrm{H}_{2}\right.$ electrolysis powered with the Swiss grid electricity), respectively. The modeling of Simons and Bauer [37] is based on a car weight of $1,434 \mathrm{~kg}$. Wu et al. [60] accounted between 30 and $230 \mathrm{~g} \mathrm{CO}_{2} / \mathrm{km}\left(\mathrm{H}_{2}\right.$ produced with wind energy vs. that from North American natural gas) for the operation of fuel cell hybrid vehicles. For a Chinese FCV, $146 \mathrm{~g} \mathrm{CO}_{2} / \mathrm{km}$ is supposed [51]. While the operational ecoefficiency of BEV is very much dependent on the electricity source, the $\mathrm{CO}_{2}$ impact of $\mathrm{FCV}$ is strongly dependent on energy and hydrogen resources used for $\mathrm{H}_{2}$ production.

Assuming a supply chain resulting in $100 \mathrm{~g} \mathrm{CO}_{2} / \mathrm{km}$ emissions over $100,000 \mathrm{~km}$, some $10 \mathrm{t}$ of $\mathrm{CO}_{2}$ is produced. This would be very similar to a Toyota Prius plug-in PHEV and only 22\% more than the operational life cycle emissions of the electric Smart (see below), which is smaller and lighter than a FCV car.

\section{Life cycle assessment of electric cars}

In order to quantify the LCA of electromobility, the impacts of electric vehicle production, maintenance and disposal on the one hand, and the impacts of operation including fuel provision on the other hand are quantified [61]. Impact of road construction, maintenance, and disposal are neglected here since there are no differences between ICEV and BEV. LCA is usually calculated separately for the glider (or platform = vehicles without engine, transmission, fuel system, or internal combustion components of any kind), the drivetrain (electric engine and associated compounds, transmission, and charging infrastructure), the battery production, and the maintenance and end-of-life treatment, respectively [61]. Other studies also distinguish subparts like inverters/electronics, the generator, and other components [42].

The overall environmental impact according to the international standard ISO EN 14040 and 14044 [62] 
includes quantification of, e.g., the abiotic depletion potential, the non-renewable cumulative energy demand [61], the acidification potential [42] and, of course, the global warming potential as $\mathrm{CO}_{2}$-equivalents. However, the global warming potentials of $\mathrm{BEV}$ production and use are discussed controversially in science and public, while the other criterions are found in the scientific debate only. We like to point out some of the critical details within the discussion and add preliminary data from a used car converted from ICE to electric.

\section{Environmental burden of the Li-ion battery production} There are only a few complete LCA studies available presenting detailed inventories [33]. Only two of them $[33,61]$ are published together with comprehensive input data and model description fully available on the internet upon title research. Some further studies are published only with limited input data and are also reviewed in the following (Table 4).

Notter et al. [61] conclude that Li-ion battery plays only a minor role (between $5 \%$ and $15 \%$ ) regarding the overall environmental burden of E-mobility, independent from the impact assessment method used. In contrast, Held and Baumann [42] calculated a global warming potential (GWP) of the battery production in the order of 5 to $10 \mathrm{t} \mathrm{CO}_{2}$-eq, dominating the GWP LCA of mini- and compact-class $\mathrm{BEV}$ propelled with renewable electricity and, furthermore, accompanied by high and dominating acidification potential of 40 to $80 \mathrm{~kg} \mathrm{SO}_{2}$-eq for the whole battery. However, Held and Baumann [42] supposed that mini- and compact-class BEV should have batteries of 20 - to $40-\mathrm{kWh}$ capacities. In contrast, the authors' converted Smart has an electrical range of more than $100 \mathrm{~km}$ with a 14-kWh Li-ion battery, sufficient for regional mobility. Compact-class BEV Nissan Leaf is said to have a cruising radius of $175 \mathrm{~km}$ with a 24-kWh battery [66]. In conclusion, battery sizes required for BEV operation seem to be partly overestimated in the literature so far (see also Table 5).

Not surprisingly, environmental costs of battery production and usage are subject to intensive scientific discussion, revealing corresponding $\mathrm{CO}_{2}$-equivalent emissions of a great variety (Table 4). However, these variations are only to a little extent due to the battery chemistry and, least of all, due to the metal lithium since a Li-ion battery contains only about $1 \%$ lithium or $80 \mathrm{~g}$ Li per kWh energy content [68]. Also, the Li purifying process is not energy-intensive [33], nor is Li related to a comparably high depletion of resources, according to Althaus et al. [68]. The $\mathrm{LiFePO}_{4}$ battery used in the Smart conversion project performed by the authors contains 3.4\% Li. Besides the Li, the $\mathrm{LiFePO}_{4}$ battery (manufacturer: Calb, China) has a content of $42 \% \mathrm{Fe}, 16 \% \mathrm{P}$, $5 \%$ graphite, $3 \% \mathrm{C}, 6 \% \mathrm{Al}$, and $10 \% \mathrm{Cu}$, respectively (MSDS accreditation certificate, 2009). The components of the highest relevance within the whole battery LCA are the anode and cathode materials graphite, copper, and aluminum [61,68]. Majeau-Bettez et al. [33], however, identified battery and components manufacturing, as well as the positive electrode paste, as being the most GWP-intensive components.

Notter et al. [61] primarily evaluated the environmental burden of a $\mathrm{LiMn}_{2} \mathrm{O}_{4}$ battery and also found that two other of the often used active materials exhibit only a small increase of $12.8 \%\left(\mathrm{Li}-\mathrm{Mn}-\mathrm{Ni}-\mathrm{Co}-\mathrm{O}_{2}\right)$ and a decrease of $1.9 \%\left(\mathrm{LiFeO}_{4}\right)$, respectively, in environmental burden (EI99H/A). This is confirmed by Majeau-Bettez et al. [33], quantifying only a $25 \%$ difference in the GWP during the production of the two different materials investigated (Table 4). Instead of the Li battery chemistry, methodical differences in LCA quantification seem to cause data deviations [49]: While the 'bottom-up'

Table $4 \mathrm{CO}_{2}$-equivalent emissions due to the Li-ion battery production

\begin{tabular}{|c|c|c|c|}
\hline Source & $\begin{array}{l}\mathrm{CO}_{2} \text {-equivalents } \mathrm{kg} / \mathrm{kWh} \\
\text { battery }\end{array}$ & $\begin{array}{l}\text { Battery chemistry } \\
\text { investigated }\end{array}$ & Remarks \\
\hline Notter et al. 2010, [61] Althaus 2011 & 52 & $\mathrm{LiMn}_{2} \mathrm{O}_{4}$ & Bottom-up LCA approach (Althaus 2011) \\
\hline Ishihara et al. 2002 [63] & 75 & Li-Ni-Co and Li-Mn & Bottom-up LCA approach (Althaus 2011) \\
\hline Zackrisson et al. 2010 [64] & 166 & $\mathrm{LiFePO}_{4}$ & $\begin{array}{l}\text { Top-down modeling from producers (Althaus } \\
\qquad 2011 \text { ) }\end{array}$ \\
\hline Frischknecht 2011 [65] & 134 & Not specified & $\begin{array}{l}\text { Top-down modeling from producers (Althaus } \\
\text { 2011) }\end{array}$ \\
\hline \multirow[t]{2}{*}{ Majeau-Bettez et al. 2011 [33] } & 250 & $\mathrm{LiFePO}_{4}$ & \multirow{2}{*}{$\begin{array}{c}\text { Industry data considered (remark by Majeau- } \\
\text { Bettez) }\end{array}$} \\
\hline & 200 & $\mathrm{LiFe}_{0.4} \mathrm{CO}_{0.2} \mathrm{Mn}_{0.4} \mathrm{O}_{0.2}$ & \\
\hline $\begin{array}{l}\text { Data range presented by five different } \\
\text { groups on the } 43 \text { rd discussion forum on } \\
\text { LCA, Zurich, } 2011 \text { (reviewed by } \\
\text { Frischknecht and Flury 2011) [67] }\end{array}$ & $(66 \text { to } 291)^{a}$ & diverse & - \\
\hline
\end{tabular}

${ }^{\mathrm{a}}$ Recalculation from original $\mathrm{kg} \mathrm{CO}$-equivalent/kg battery data according to measurements of the $\mathrm{LiFePO}_{4}$ battery installed into the Smart in the laboratory of the authors (161 kg of weight, 14-kWh capacity), which reproduces well the numbers reported in detail by Notter et al. [61] and Zackrisson et al (2010) [64]. 
Table 5 Characteristics of electric cars (compact class) today in comparison with the converted Smart

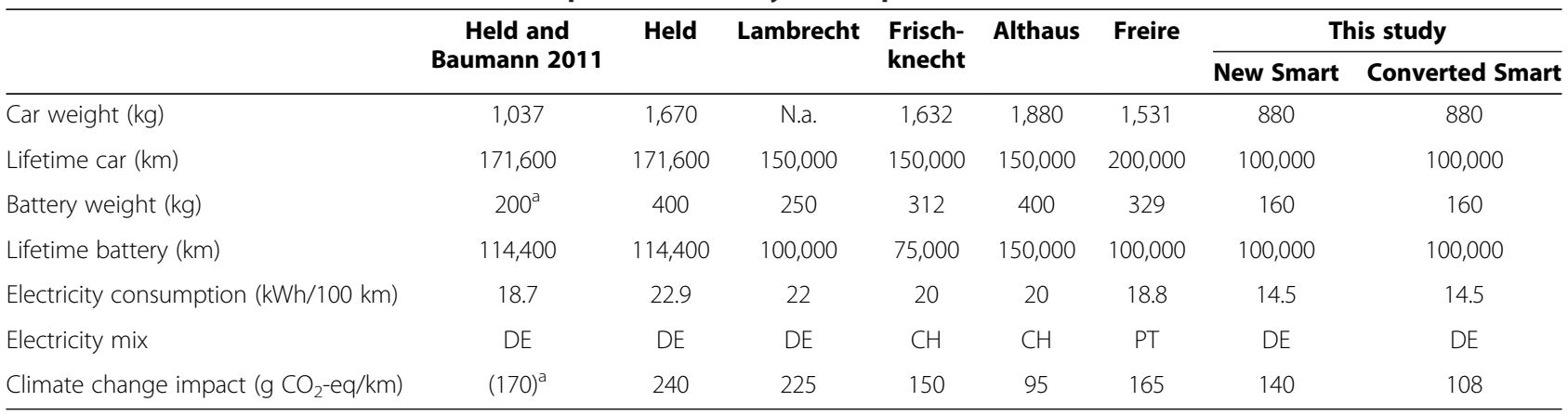

$\mathrm{N} . \mathrm{a}=$ not available, $\mathrm{DE}=$ Germany, $\mathrm{CH}=$ Switzerland, $\mathrm{PT}=$ Portugal.

Characteristics of electric cars (compact class) today and climate change impacts of driving $1 \mathrm{~km}$ (data from Held, Lambrecht, Frischknecht, Althaus and Freire presented on a conference 2011 and taken from Frischknecht and Flury [67]) in comparison with the converted Smart presented in this study. ${ }^{\mathrm{a}} \mathrm{Calculated}$ from data reported by Held and Baumann [42].

method of, e.g., Notter, Althaus, and Ishihara leads to lower $\mathrm{CO}_{2}$-equivalent emissions, a 'top-down' approach (Zackrisson and Frischknecht) seems to generate higher results (Table 4). In addition to the different approaches to quantify costs of Li battery production, the application scenario has to be defined, which is a theoretical attempt since there is no widespread use of electric cars yet in everyday life: What is the annual distance traveled with an electric car? How many years will an electric car be in operation? How long does a battery in a car last? The latter depends on battery chemistry, its cycle strength, the quality of production, and pattern of everyday use. Also important is how charging is performed in everyday life quick (at higher currents) or slow - and to which temperature fluctuations the battery will be exposed. Statistically usable data are not expected before BEV has been brought on the streets for routine use.

In conclusion, LCA database, so far, for Li-ion battery production still seems to be in substantial movement. This is even more the case when electricity sources change from fossil to renewable. Tao et al. [69] claim that $\mathrm{CO}_{2}$ emissions from electricity consumption during Li-ion battery production can be reduced by $95 \%$ to $98 \%$ if the production site is shifted from China/Europe to Iceland with its geothermal energy resources. Electricity production in Iceland causes a footprint of 18 to $23.5 \mathrm{~g}$ $\mathrm{CO}_{2} / \mathrm{kWh}$ only [69].

$\mathrm{CO}_{2}$-life cycle impact of the converted Smart (BEV vs. ICEV) Carbon footprint and environmental impact quantification of standard automobile parts can be expected to generate less volatile data than the Li-ion battery. The glider, a car minus motor, gearbox, and fuel equipment, is taken as a useful basis for modeling [61]. A full LCA of automobile use includes an impact quantification of the glider's production, the manufacturing of propulsion components (in an ICEV - the combustion engine, gearbox, and fuelling system; in a BEV - the electric engine plus electric controller system) rather than, for a $\mathrm{BEV}$, the footprint of battery production. $\mathrm{CO}_{2}$ emission during operation of the car is quantified considering the consumed carbon-based fuel (ICEV) or indirect $\mathrm{CO}_{2}$ emission during electricity production (BEV). Even if a detailed LCA modeling of an individual car is not available for all its technical parts, a simplified life cycle assessment can be performed with comparative calculations based on LCA models published in detail: As an example, lifetime carbon footprints were estimated here according to the conversion of a used Smart in the laboratory of the authors (Figure 2). The LCA for the glider, drivetrain, and battery of the Smart were recalculated based on the data by Notter et al. [61]. Measured weights of the Smart's glider, the gearbox (kept), the new electric motor, the battery as well as the controller, and further accessory parts were converted relative to the carbon footprint data by Notter et al. [61]. The detailed material composition of the glider was not considered in this assessment. However, unlike the LCA data published so far, this estimation is not based on modeled cars but on a used car purchased on the market and then converted to electric. Also, different to most of the published data, petrol and electricity consumptions of the same car were measured prior to and after the technical conversion: The Smart has been driven along the same route and the same street conditions before and after electric conversion.

Real street data were chosen to evaluate the energy consumption. The ICEV Smart belongs to cars with some of the highest deviations between certified and reality fuel consumption (up to $60 \%$ [1]). We chose a mileage of $100,000 \mathrm{~km}$ on the assumption that the first battery will be kept within this range. Also, fossil-fuelled Smarts, on the other hand, can be expected to drive between 60,000 and $120,000 \mathrm{~km}$ with the first engine according to our knowledge, which allows a comparison between the ICEV and the electric version over 100,000 


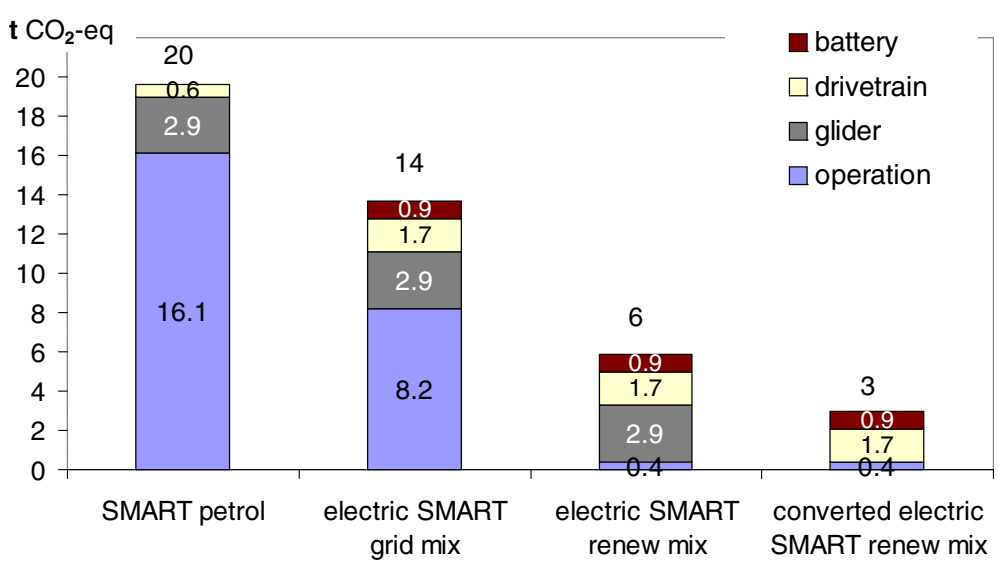

Figure $2 \mathrm{CO}_{2}$ life cycle assessment based on a converted Smart car. Preliminary and simplified $\mathrm{CO}_{2}$ life cycle assessment based on data obtained during a conversion of a used Smart from an ICEV to a BEV. Calculation conditions: 100,000 km lifetime, grid electricity $563 \mathrm{~g} \mathrm{CO}_{2} / \mathrm{kWh}$ (German Federal Environmental Agency, number for 2010), and renewable electricity mix $30 \mathrm{~g} \mathrm{CO}_{2} / \mathrm{kWh}$ (reviewed in [5]). Smart I model, petrolfuelled, built in the year 2000 (also calculated as being 'new'), and purchased in 2011 with 106,000 km driven. ICE engine, tank components, and exhaust system were removed, gearbox was kept. Fuel chain emissions of $2.88 \mathrm{t}$ (included in $16.1 \mathrm{t}$ operation emissions) calculated according to Öko-Institut [56] for petrol provision. $\mathrm{CO}_{2}$ impacts of the battery, drivetrain, and glider production calculated according to Notter et al. [61]. Weight of the glider, $597 \mathrm{~kg}$. Cutoff allocation rule applied for the glider in column 4 (converted Smart). Electric engine including gearbox and all accessories weigh $122 \mathrm{~kg}$; battery weight is $161 \mathrm{~kg}$. Further information is provided in the text.

km. Operation emissions are both dominating the $\mathrm{CO}_{2}$ life cycle of the fossil fuel-propelled Smart (column 1, Figure 2) as well as an electric Smart (column 2, Figure 2) if charged with German mean grid electricity. This is in accordance with the findings of Helms et al. [40] as well as Notter et al. [61]. Other studies report higher BEV $\mathrm{CO}_{2}$ life cycle impacts during operation when charged with grid mix, e.g. Helms et al. [40] with approximately $20 \mathrm{t}$ (mid-size car) and Held and Baumann [42] also with approximately $20 \mathrm{t}$ (mini-class), however recalculated for 150,000 to $171,600 \mathrm{~km}$ of operation. Other differences will partly be due to a higher battery and car weight (Table 5). However, we calculated the direct $\mathrm{CO}_{2}$ emissions due to fuel combustion (including fuel chain emissions) as well as indirect $\mathrm{CO}_{2}$ emissions due to consumption of the German grid electricity (for details, see explanatory notes in Figure 2). Calculation of $\mathrm{CO}_{2-}$ equivalents based on ecoinvent 2.2 database adds up to 9.4 $\mathrm{t}$ instead of $8.2 \mathrm{t}$ for the operation phase of the electric Smart (column 2 in Figure 2).

Literature comparison of the Smart e-conversion carbon footprint According to our simplified LCA model, life cycle $\mathrm{CO}_{2}$ emissions could be reduced by $30 \%$ when switching from the petrol version to a new electric Smart (Figure 2). Fuelling the electric Smart with renewable electricity mix causes an additional $55 \%$ reduction of life cycle $\mathrm{CO}_{2}$ emissions (second and third column in Figure 2). However, we have chosen an already driven Smart with combustion engine over 100,000 km and converted it, so we can omit expenditure for the glider production (cutoff rule); this way halved again the life cycle $\mathrm{CO}_{2}$ emissions and ended up with $2.8 \mathrm{t}$ (from column 3 to column 4 in Figure 2). Altogether, life cycle $\mathrm{CO}_{2}$ emissions when driving a Smart have been reduced by $86 \%$ due to this model (Figure 2, from the first to the last column). Life cycle $\mathrm{CO}_{2}$ emissions for the new electric Smart (first column in Figure 2) and, not shown in Figure 2, that of a converted used Smart propelled with German electricity mix (10.8 t in lifetime) are selected to calculate the overall $\mathrm{g} \mathrm{CO}_{2} / \mathrm{km}$ impacts in Table 5.

Other findings in Table 5 need to be commented: Electric Smart has the lowest climate change impact, which was expected since it is the smallest car. It confirms a finding already published [49]: The smaller the BEV, the more ecoefficient it is. This is also known from ICEV; however, it is more pronounced within BEV due to the high battery weight.

The data published by Althaus and Frischknecht (Table 5) seem to be in compliance with the Smart numbers. However, Althaus and Frischknecht modeled BEV twice the Smart's weight and even heavier. On the other hand, they based their life cycle emissions evaluation on Swiss electricity consumption. Swiss electricity GHG intensity is around $140 \mathrm{~g} \mathrm{CO}_{2}$-eq/ $/ \mathrm{kWh}$ (number for 2005 [37]), while in Germany, $563 \mathrm{~g} \mathrm{CO}_{2} / \mathrm{kWh}$ (number for 2010, see above) must be taken into account. Lambrecht, Held as well as Held and Baumann [42] published larger climate change impacts. This is evident particularly for data extracted from Held and Baumann [42] based on a mini-class car quite comparable to the Smart. Since the carbon footprint we calculated for the Smart and Held 
and Baumann [42] calculated for a mini-class car (around $3 \mathrm{t} \mathrm{CO}_{2}$ ) for the platform (glider) is nearly the same, the deviation is due to a higher electricity consumption of $18.7 \mathrm{kWh} / 100 \mathrm{~km}$ assumed by Held and Baumann [42]. Also, more than $6 \mathrm{t} \mathrm{CO}_{2}$ was modeled by Held and Baumann [42] for production and maintenance of the battery, which is six times more than we assumed based on the data by Notter et al. [61].

Charging the Smart with electricity of renewable origin (30 $\mathrm{g} \mathrm{CO}_{2} / \mathrm{kWh}$ ), however, would considerably decrease the overall climate change impact; the climate change impact of a new electric Smart would be more than halved on $63 \mathrm{~g} \mathrm{CO}_{2} / \mathrm{km}$, and the impact of the converted Smart is down to $30 \mathrm{~g} \mathrm{CO} / \mathrm{km}$, each calculated for $100,000 \mathrm{~km}$ of operation (not shown in Table 5).

Life cycle impact of plug-in hybrid electric vehicles Samaras and Meisterling [70] published ICEV life cycle $\mathrm{CO}_{2}$-equivalent costs in the order of $270 \mathrm{~g} / \mathrm{km}$ and for $\mathrm{HEV}$ of 180 to $190 \mathrm{~g} / \mathrm{km}$, respectively. Interestingly, with increasing the battery size of PHEV, CO2-equivalents decrease only little in the order of a few grams per kilometer [70]. Similarly, Helms et al. [40] reported life cycle $\mathrm{CO}_{2}$-equivalent emissions for PHEV in the order of 150 $\mathrm{g} / \mathrm{km}$, operated with German average electricity $(150,000$ $\mathrm{km}$ life cycle). Their data revealed advantages for BEV over PHEV only in combination with wind power [40]. Due to high battery production costs assumed, Held and Baumann [42] found advantages of PHEV over BEV in the criterions GWP and acidification potential $\left(\mathrm{SO}_{2}-\right.$ equivalent), with the latter not being confirmed by Helms et al. [40]. Also, Althaus [49] stated that 'electric vehicles with sufficient battery capacity for normal use and a range extender for special use perform better than electric vehicles with larger batteries'.

Life cycle impact categories other than global warming potential Life cycle categories further than GWP implemented in LCA reports on electric cars published so far are abiotic depletion potential and non-renewable cumulative energy demand. Notter et al. [61] aggregated the three categories by the Ecoindicator 99 method, concluding that the environmental burden of BEV is significantly lower compared to ICEV. Aggregation to Ecoindicator 99 method revealed an environmental impact of $\mathrm{BEV}$ around 37\% below that of ICEV. Althaus [49], however, pointed out additionally that BEV charged with electricity with a significant portion of nuclear energy will be associated with a backpack of nuclear waste production. Also, he identified disadvantages of BEV compared to ICEV in the land use category and, particularly noticeable, in the human toxicity potential category, both due to the production of the lithium battery. On the other hand, there are advantages of BEV over ICEV in the impact criterions resource damage and photochemical oxidation potential [49]. Also, Held and Baumann [42] found out about a distinct disadvantage of BEV in the acidification potential. This is due to the sulfur emissions during the smelting of metals like $\mathrm{Cu}$ and $\mathrm{Ni}$ and may also be due to associated $\mathrm{SO}_{2}$ emissions when components are produced in countries like China, where electricity production is dominated by coal-fired power plants. However, there are differences within the batteries: $\mathrm{LiFePO}_{4}$ batteries have a lower acidification potential since they contain no nickel [71].

Helms et al. [40] did not report elevated acidifying emissions accompanying the BEV production but emphasized the $\mathrm{SO}_{2}$ emissions during $\mathrm{BEV}$ operation caused by electricity production from coal. This was confirmed by Helmers [1], who calculated the $\mathrm{SO}_{2}$ emissions accompanying the power usage of a BEV in Germany based on year 2006 data, revealing up to tenfold higher indirect $\mathrm{SO}_{2}$ emissions of a $\mathrm{BEV}$ compared to ICEV direct $\mathrm{SO}_{2}$ emissions. Indirect $\mathrm{BEV}$ emissions of $\mathrm{NO}_{x}$ and fine dust according to electricity production, however, were smaller than direct ICEV emissions [1]. Majeau-Bettez et al. [33] quantified the LCA emissions of battery production and use, reporting 14 to $19 \mathrm{~g} \mathrm{CO}_{2}$ eq $/ \mathrm{km}$ (battery only) for two Li-ion batteries (specified in Table 4). They quantified a lot of additional impact categories (freshwater and terrestrial ecotoxicity, freshwater eutrophication, marine ecotoxicity, metal depletion, ozone depletion, and particulate matter formation) to those mentioned above and concluded that Li-ion batteries are environmentally favorable compared to the NiMH battery [33].

\section{Conclusions}

The electric car seems to be a suitable instrument and a sustaining measure towards a more sustainable mobility future since it is four times more energy efficient compared to ICEV. Therefore, it is seen as a milestone towards a 'Great Transformation' [4]. The TTW efficiency advantage of BEV over ICEV, together with the efficiency jump by Li-ion batteries, enable the electrification of the automobile as long as it is moved in regional ranges of up to $100 \mathrm{~km}$ per day. However, WTW efficiency of electric cars can reach exemplary figures only when electricity is provided by very efficient power plants and infrastructure, best with renewable energy production. Also, electric cars should be incorporated into a variety of modern mobility concepts (e.g., [72]).

Energy efficiency of an FCV propelled with hydrogen is only slightly lower compared to BEV; however, a lot of energy is lost during production and provision of compressed $\mathrm{H}_{2}$ even in the case of water electrolysis powered with renewable electricity. Also, hydrogen filling station infrastructure is missing and would be very expensive to build up, different to the charging infrastructure needed for electric cars. 
Life cycle assessment of electric car mobility according to the literature already available is complex. Most LCA data deal with the global warming potential. Since $\mathrm{CO}_{2}$ equivalents emission during the operation is dominating the LCA in total, an electric car can already have ecoefficiency advantages when charged with grid electricity $(500$ to $600 \mathrm{~g} \mathrm{CO}_{2} / \mathrm{kWh}$ presumed). However, charging the electric car with renewable electricity $\left(30 \mathrm{~g} \mathrm{CO}_{2} / \mathrm{kWh}\right)$ improves its LCA performance significantly. Ecoimpact of smaller BEV is also much better according to the high ecoimpact of the battery, which must increase parallel to the size of the car. Some LCA studies published so far modeled quite heavy $\mathrm{BEV}$, which are additionally assumed to drive periodically at higher speeds, both inefficient for a BEV. In contrast, a small BEV like the electrified Smart presented here and moved locally as well as regionally only can have the most beneficial $\mathrm{CO}_{2}$-impact. During an econversion of a used car, as shown with the Smart, life cycle $\mathrm{CO}_{2}$ emissions can be reduced by more than $80 \%$ compared to that known from ICEV. However, this is a first estimation under optimistic assumptions (e.g., battery lifetime), which is planned to be critically reviewed in a more detailed model later.

Life cycle impact of BEV in categories other than the global warming potential reveals a complex picture, although BEV demonstrates advantages over ICEV in most categories. Althaus [49] even concludes that 'carbon footprint is not sufficient as environmental performance indicator' here. One disadvantage of BEV is the acidification potential associated with the smelting processes of $\mathrm{Cu}, \mathrm{Ni}$, and Co since a lot of $\mathrm{Cu}$ and, in some battery types, $\mathrm{Ni}$ and $\mathrm{Co}$ also are essential elements of electrical components. Additionally, there are acidifying emissions of coal-fired power plants depending on the local value of this type of power production. However, to what extent the local nearly zero-emission advantage of electric cars is incorporated into LCA models is still a question. Toxic emissions like $\mathrm{NO}_{\mathrm{x}}$ and fine dust are today shifted to power plants through the use of BEV (quantified in [1]), where it is easier to limit and control them. The BEV advantage of a much lower noise emission, for example, is not appreciated so far (a guideline is in preparation).

\section{Competing interests}

The authors declare that they have no competing interests.

\section{Acknowledgements}

The authors like to thank Katharina Schowalter, Rüdiger Hild and Bernd Fuss for data provision and Viola Helmers for the linguistic comments on the manuscript. We also appreciate the advice by M. Gauch and particularly G. Majeau-Bettez.

\section{Authors' contribution}

EH carried out the whole manuscript despite of the Technology section which was carried out by both authors. PM carried out the electric conversion of the used Smart. EH corrected and approved the final manuscript.

Received: 6 December 2011 Accepted: 26 April 2012

Published: 26 April 2012

References

1. Helmers E: Bewertung der Umwelteffizienz moderner Autoantriebe - auf dem Weg vom Diesel-PKW-Boom zu Elektroautos. Umweltwiss Schadst Forsch. 2010, 22:564-578.

2. Angerer $G$, Marscheider-Weidemann F, Wendl M, Wietschel M: Lithium for future technologies - demand and supply with special emphasis on electric vehicles (in German):http://www.elektromobilitaet.fraunhofer.de/ Images/.

3. WHO: Air quality and health.:http://www.who.int/mediacentre/factsheets/ fs313/en/index.html.

4. German advisory council on global change (WBGU): World in transition: A social contract for sustainability.:http://www.wbgu.de/fileadmin/templates/ dateien/veroeffentlichungen/hauptgutachten/jg2011/wbgu_jg2011_en.pdf.

5. Helmers E: Bitte wenden Sie jetzt - das Auto der Zukunft. Weinheim: Wiley VCH; 2009:204

6. UNEP: Hybrid electric vehicles. An overview of current technology and its application in developing and transitional countries.:http://www.unep. org/transport/pcfv/PDF/HEV_Report.pdf.

7. Halderman JD, Martin T: Hybrid and Alternative fuel vehicles. New Jersey: Pearson Prentice Hall; 2008:448.

8. Nemry F, Brons M: Plug-in hybrid and battery electric vehicles. http://ftp.jrc.es/ EURdoc/JRC58748_TN.pdf.

9. Larminie J, Lowry J: Electric vehicle technology explained. Chichester: John Wiley \& Sons; 2003:303

10. Angerer G, Erdmann L, Marscheider-Weidemann F, Scharp M, Lüllmann A, Handke V, Marwede M: Raw materials for future technologies (in German). http://www.isi.fraunhofer.de/isi-de/n/download/publikationen/ Schlussbericht_lang_20090515_final.pdf.

11. Podewils C: Power for good times (in German). Photon 2010, 2010:36-46.

12. Amirault J, Chien J, Garg S, Gibbons D, Ross B, Tang M, Xing J, Sidhu I, Kaminsky $P$, Tenderich B: The electric vehicle battery landscape: opportunities and challenges. http://cet.berkeley.edu/dl/BatteryBrief_final.pdf.

13. Gerschler B, Sauer DU: Batterien für Elektrofahrzeuge - Stand und Ausblick. Presentation, Berliner Energietage 2010.

14. Kloess M: The role of plug-in-hybrids as bridging technology towards pure electric cars: an economic assessment. http://publik.tuwien.ac.at/files/ PubDat_191393.pdf.

15. Kavalov B, Peteves SD: Impacts of the increasing automotive Diesel consumption in the EU. http://www.eirc-foundation.eu/Publications/ Energy/EUR\%2021378\%20EN.pdf.

16. Forschungsstelle für Energiewirtschaft: Energieeffizienz alternativer Kraftstoffe aus Biomasse und Erdgas im Vergleich mit konventionellen Kraftstoffen. http://www.wiba.de/download/wiba_p6.pdf.

17. Fritsche UR: Endenergiebezogene Gesamtemissionen für Treibhausgase aus fossilen Energieträgern unter Einbeziehung der Bereitstellungsketten. Kurzbericht im Auftrag des Bundesverbands der deutschen Gas- und Wasserwirtschaft e.V. Darmstadt: Öko-Institut 2007, :14

18. European Union: Well-to-Wheels analysis of future fuels and associated automotive powertrains in the European context. http://www.lowcvp.org. uk/assets/presentations/CONCAWE_WTW_CNG_preliminary_Sept_03.pdf.

19. Nylund NO, Laurikko J, Ikonen M: Pathways for natural gas into advanced vehicles. Part A: technology and fuels for new generation vehicles. http:// www.bctia.org/files/PDF/transportation/Natural_Gas_for_Advanced_Vehicles__2003.pdf.

20. International Energy Agency: Hydrogen production and distribution. IEA Energy Technology Essentials 2007, 5:1-4.

21. Kloess M: The road towards electric mobility - an energy economic view on hybrid- and electric vehicle. http://publik.tuwien.ac.at/files/ PubDat_183277.pdf.

22. EU: Well to wheel analysis of future automotive fuels and powertrains in the eurpopean context. http://www.co2star.eu/publications/ Well_to_Tank_Report_EU.pdf.

23. Husain I: Electric and hybrid vehicles - design fundamentals. 2nd edition. Boca Raton: CRC press; 2011. 490 pp. 
24. Simpson A: Full-Cycle assessment of alternative fuels for light-duty road vehicles in Australia. http://www.autospeed.com.au/static/downloads/articles/ 110155_UPDATED_Full-Cycle_Assessment_of_Alternative_Fuels_for_LightDuty_Road_Vehicles_in_Australia.pdf.

25. An F, Santini D: Assessing tank-to-wheel efficiencies of advanced technology vehicles. http://cta.ornl.gov/TRBenergy/trb_documents/ an_assessing_tank.pdf.

26. Pelz N: Alternative Kraftstoffe für Kraftfahrzeuge und ihre Möglichkeit zur $\mathrm{CO}_{2}$-Einsparung. In Im Spannungsfeld zwischen $\mathrm{CO}_{2}$-Einsparung und Abgasemissionsabsenkung. Renningen: Expert-Verlag; 2008:260.

27. Steiger W: In Synthetic fuels - key for future power trains. In Which fuels for low $\mathrm{CO}_{2}$ engines. Edited by Pierre D. Paris: Technip; 2004:233.

28. Bossel U: Does a hydrogen economy make sense? Proc IEEE 2006, 95(10):1826-1837.

29. Hacker F, Harthan R, Matthes F, Zimmer W: Environmental impacts and impact on the electricity market of a large scale introduction of electric cars in Europe. http://acm.eionet.europa.eu/docs/

ETCACC_TP_2009_4_electromobility.pdf

30. Sullivan JJ, Baker RE, Boyer BA, Hammerle RH, Kenney TE, Muniz L, Wallington TJ: $\mathrm{CO}_{2}$ emission benefit of diesel (versus gasoline) powered vehicles. Environ Sci Tech 2004, 38(12):3217-3223.

31. Albus C: WLTP-development - UNECE and the parallel EU process. [http:// circa.europa.eu/Public/irc/enterprise/automotive/library?|=/ cars_working_groups/internal_emissions/meeting_24012011/ presentation_germanypdf/_EN_1.0_\&a=d].

32. Arnold K, Dienst C, Lechtenböhmer S: Integrierte Treibhausgasbewertung der Prozessketten von Erdgas und industriellem Biomethan in Deutschland. Umweltwiss Schadst Forsch 2010, 22:135-152.

33. Majeau-Bettez G, Hawkins TR, Strømman AH: Life cycle environmental assessment of lithium-ion and nickel metal hydride batteries for plug-in hybrid and battery electric vehicles. Environ Sci Technol 2011 45(10):4548-4554.

34. Auto Motor Sport: 2011, January (3) 128-131.

35. Matsunaga M, Fukushima T, Ojima K: Powertrain system of Honda FCX Clarity fuel cell vehicle. World Elec Vehicle J 2009, 3:1-10.

36. DWV: Wasserstoff: Der neue Energieträger. http://www.dwv-info.de/ publikationen/2009/etraeger3.pdf

37. Simons A, Bauer C: Life cycle assessment of hydrogen use in passenger vehicles. http://www.thelma-emobility.net/pdf/IAMF\%202011/ IAMF2011_Simons.pdf

38. Linssen J, Grube T, Hoehlein B, Walbeck M: Full fuel cycles and market potentials of future passenger car propulsion systems. Int J Hydrogen Energ 2003, 28:735-741.

39. Joint Research Center: Well-to-wheels analysis of future automotive fuels and powertrains in the European context. http://ies.jrc.ec.europa.eu/TWT.

40. Helms H, Pehnt M, Lambrecht U, Liebich A: Electric vehicle and plug-in hybrid energy efficiency and life cycle emissions. http://www.ifeu.de/ verkehrundumwelt/.

41. Pehnt M, Helms $H$, Lambrecht U, Lauwigi C, Liebich A: Umweltbewertung von Elektrofahrzeugen. Erste Ergebnisse einer umfassenden Ökobilanz. 14th Internationaler Kongress Elektronik im Kraftfahrzeug 2010. VDI-Berichte Elektronik im Kraftfahrzeug, Band Nr 2010, 2075:21-40.

42. Held M, Baumann M: Assessment of the environmental impacts of electric vehicle concepts. In Towards life cycle sustainable management. Edited by Houten Finkbeiner M.: Springer Media; 2011:535-546.

43. Mitsubishi innovative electric vehicle http://www.imiev.de/docs/iMiEV-daten. pdf.

44. Nissan Netherlands www.nissan.nl.

45. ADAC-Motorwelt. 2011, February.

46. Eberhard $M$, Tarpenning $M$ : The $21^{\text {st }}$ century electric car. http://www.fcinfo. jp/whitepaper/687.pdf.

47. About the ratings. http://www.fueleconomy.gov/feg/ratings2008.shtml.

48. Auto Motor Sport June 2011 (15), 106-109.

49. Althaus $\mathrm{HJ}$ : Comparative assertion of battery electric cars with various alternatives. http://empa.ch/plugin/template/empa/*/109103.

50. International Energy Agency: $\mathrm{CO}_{2}$ emissions from fuel combustion - highlights. http://www.iea.org/co2highlights/co2highlights.pdf.

51. Yan X, Crookes RJ: Energy demand and emissions from road transportation vehicles in China. Prog Energy Combust Sci 2010, 36:651-676.

52. German Federal Environmental Agency.

53. Opel Germany www.opel.de.
54. Auto Motor Sport: 14.6.2011.

55. AutoBild. 8.7.2011.

56. Öko-Institut: Endenergiebezogene Gesamtemissionen für Treibhausgase aus fossilen Energieträgern unter Einbeziehung der Bereitstellungsketten. Darmstadt; 2007:14.

57. www.adac.de. 11/2011

58. AutoBild. 10.6.2011.

59. Höhlein B, Grube T: Kosten einer potenziellen Wasserstoffnutzung für E-Mobilität mit Brennstoffzellenantrieben. Energiewirtschaftliche Tagesfragen 2011, 61(6):62-66.

60. Wu Y, Wang MQ, Sharer PB, Rousseau A: Well-to-wheels results of energy use, greenhouse gas emissions and criteria air pollutant emissions of selected vehicle/fuel systems. SAE Transactions 2007, 115:210-222.

61. Notter DA, Gauch M, Widmer R, Wäger P, Stamp A, Zah R: H-J Althaus: Contribution of Li-ion Batteries to the Environmental Impact of electric vehicles. Environ Sci Tech 2010, 44:6550-6556.

62. Klöpffer W, Grahl B: Ökobilanz (LCA). Weinheim: Wiley-VCH; 2009. 426 pp.

63. Ishihara K, Kihira N, Terada N, Iwahori T: Environmental burdens of large Li-ion batteries developed in a Japanese national project. In Central research institute of electric power industry, 202 ${ }^{\text {nd }}$ meeting: 2002, October 20-25; Salt Lake City.

64. Zackrisson M, Avellan L, Orlenius J: LCA of Li-ion batteries for plug-in hybrid electric vehicles - critical issues. J Clean Prod 2010, 18:1517.

65. Frischknecht R: LCA of driving electric cars and scope dependent LCA models. In 43'd LCA Forum. Zürich; 2011.

66. Nissan Netherlands brochure. 2011.

67. Frischknecht $R$, Flury $K$ : Life cycle assessment of electric mobility: answers and challenges - Zurich, April 6, 2011. Int J Life Cycle Assess 2011, 16:691-695.

68. Althaus HJ, Notter D, Gauch M, Widmer W, Wäger P, Stamp A, Zah R: LCA of Li-ion batteries for electric mobility. http://www.empa.ch/plugin/template/ empa/*/104371.

69. Tao PC, Stefansson H, Harvey W, Saevarsdottir G: Potential use of geothermal energy sources for the production of Li-ion batteries. In Word Renewable Energy Congress. Linköping: WREC; 2011:8. 8-13.

70. Samaras C, Meisterling K: Life cycle assessment of greenhouse gas emissions from plug-in hybrid vehicles: implications for policy. Environ $\mathrm{SCl}$ Tech 2008, 42:3170-3176.

71. Chanoine A: Comparative LCA of NiCd batteries used in cordless power tools vs. their alternatives $\mathrm{NiMH}$ and Li-ion batteries. http://ec.europa.eu/ environment/waste/batteries/pdf/biois_Ica_18072011.pdf.

72. Canzler W, Knie A: Einfach aufladen - mit Elektromobilität in eine saubere Zukunft. München: Oekom Verlag; 2011. 121 pp.

doi:10.1186/2190-4715-24-14

Cite this article as: Helmers and Marx: Electric cars: technical

characteristics and environmental impacts. Environmental Sciences Europe 2012 24:14

\section{Submit your manuscript to a SpringerOpen ${ }^{\odot}$ journal and benefit from:}

- Convenient online submission

- Rigorous peer review

- Immediate publication on acceptance

- Open access: articles freely available online

- High visibility within the field

- Retaining the copyright to your article

Submit your next manuscript at $>$ springeropen.com 